\title{
疽料 解說
}

\section{示差熱分析 裝 置}

An Apparatus for Differential Thermal Analysis

須 藤 俊 男* (Toshio Sudo)

序

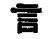

示差熱分析 (differntial thermal analysis) は, 古く 1887年フランス の H. Le Chateliar) によりはじめて考案されたるらであるが, 最近におい て注世界を通じて，一つの大きい流行（言葉沬多少不適当己思うが）の徽に ある。すをわち每月発行される地質鉱物関係の專門雜誌に，この示差熱分析 曲線（一般にこれを D. T. A. 曲線と略称する）が記載されていないことは 少ない位で，しかも最近には粘土鉱物のみならす，その他の炭酸塩鉱物2) 燐

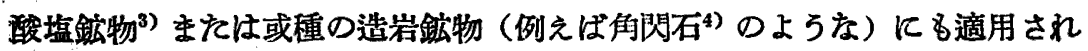
また推積岩の研究 ${ }^{5}$ 《も利用されつつある。

1950年秋に筆者の研究室において, 示差熱分析曲線の研究が開始せられて 上来, その裝置及び結果について，各方面より注目せられ，也ふの問合せが あるので,ここに簡単な報告を試みる次第である。

\section{原理}

示差熱分析の原理は既によく知られているように,試料と熱的不活性体(普 通はフルミナを用いる）を複熱電対で結び，これを電気㭁の中に設置し，师 の溫度を一定の割合で上昇させ，試料の脫水分解，または変態の時生亦る熱 的変化 (吸熱または発熱)を炉の溫度之共に記錄する方法である。

各研究者の使用する裝置は，この原理を実験に移している点では共通であ るが，裝置の具体的の点になると，研究者によつて必ずしも一致していな

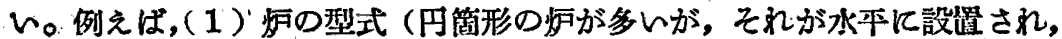
または重直設置されている)，(2) 試料支持器の型式 (これは最も変化が 多ん), (3) 記錄裝置の型式 (写真式, 自記記錄電位差計, 手記など), (4)

* 東京大学理学部地質学敨 
溫度の上昇率 ( 1 分間 $5^{\circ} \mathrm{C}$ 位から最高 $15^{\circ} \mathrm{C}$ 位まである) などである。

\section{現牀}

すなわちこのような裝置の其体的の点になると,各研究者によつてかなり 異をつていることがあり，例えばアメリカにおいては，はつきりしたいくつ

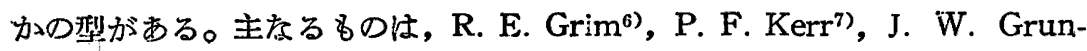
$\mathrm{er}^{3)}$ 及びアメリカの鉱山局の方式》 などである。そして，示差熱分析曲線を 記錄してこれを発表する場合には，用いた裝置に独特の考案がなされていな い限り，必利「誰及の方式による」と明記して礼節を保つていることは学ぶ べき点である。

日本においては，种津淑神先生" が示差熱分析曲線を発表された最初であ る。その後, 最近まで, 絕えてこの種の研究が無かつたが, ついで, 東京工 業大学の河島千尋教授 ${ }^{(0)}$ が, 主として, 篦業原料につを, 最も活潑な実験を 続けられた。ついで，早稻田大学の大坪義雄助敉授》は，装置を設固され， 酸性白土の研究にこの熱分析を利用された。この間, 当時京都大学にあつた 小泉光惠氏も，沸石の研究に示差熱分析曲線を利用されたのである。

これらの方々に次いで，筆者の研究窒でも示差熱分析曲線の記錄が開始せ られた。1950年春より，篗者は，主として，汀島敎授の裝置を参照し，数ヶ 所の点を多少改良し,裝㯰の製作をはじめ，同年秋より実験が開始せられた。 この当初の実験には, 現在名古屋大学地球化学科にある長沢敬之助氏の努力 によること大である。

このように篗者の笑験裝㯰は，沈して日本で最初のものではなかつたので あるが;実験結果においては,従来の日本のデーターにはあまり見られなかつ ね程，滑らかな曲線が得られた点，しかる，あらゆる型の粘土鉱物及びそれ に関連せる鉣物の曲線を多く記錄することが出来た点において，日本の地質 鉱物学界で最初であつたため，多大の注意をひいた。その後，地質鉱物学界

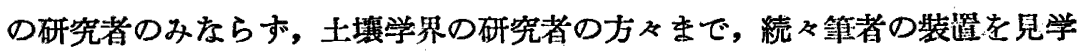
し，参照せられて，装置の組立をはじめられ，中には，すでに完成して，同 栐の良結果を得ていられるところもある。

現在篗者の実験室では，白金炉とニクロム線炉と老交互に用いて，一日平

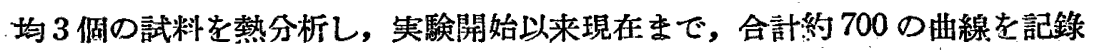
し, その中には, 粘土, 土壤, 熱水変質を受けた母岩, 堆積岩なども含んで いる。これらについては一部は既に発表したが12)今後折をみて, 続いて発表 の機会を持ちたいと考えている。 


\section{勧者の実験蛪に設置されてある裝置}

現在篗者の実験室で使用されている裝置は次の如くである。

(a) 器具

電気炉：白金線撩及びニクロ 內徑 $5.7 \mathrm{~cm}$, 臣さ $30 \mathrm{~cm}$, 內ばりの耐火物円简の厚さは, 約 $5 \mathrm{~mm}$ であつて 庐の一方の口は密閉してある。いずれる100V. こ0 A であつて, 最高溫度は

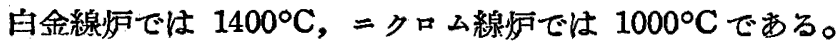

変圧器 : $3 \mathrm{KW}$ 。

抵据器 : 检型 1 5000オーム

アンメーター：30アンペア。

高溫計：横河電気製作所, Hp $\sim S$, 內部抵抗, 789 オーム。

検流計：楣河電気製作所,D3 型C級；線輪抵抗 46オーム, 外 部臨界制動抵抗，52オ一ム，感 度, $4.1 \times 10^{-9} \mathrm{~A}, 4.0 \times 10^{-7} \mathrm{~V}$, 週期 9.5 秒。

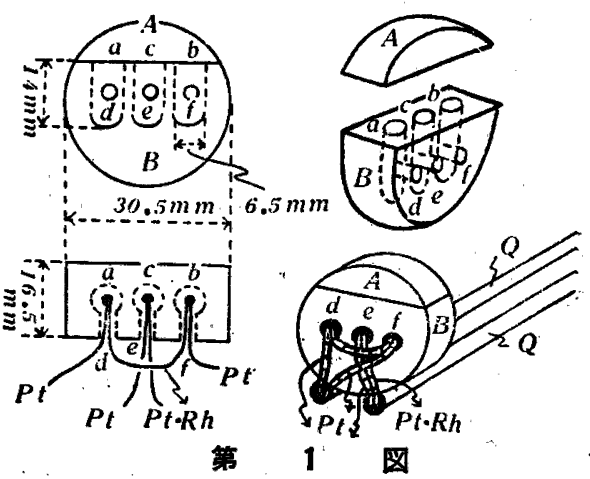

$$
\text { ランプスケール。 }
$$

熱電対：白金一白金ロヂウム（ロヂウム $13 \%$ )，徑 $0.42 \mathrm{~mm}$ ，長さ $2 \times 500$ $\mathrm{mm}$ のの一本, 及び徑 $0.42 \mathrm{~mm}$, 長さ約 $2 \times 500 \mathrm{~mm}$ の複熱電対一本。

補償導線 : 約 $2 \mathrm{~m}$ 。

冷接点用魔法瓶：白金一白金ロヂウム（ロデウム $13 \%$ ) 用。

小さい切かえスイツチ。

試料支持器（須藤式)(第 1 図)：=クロム 2 号の金属でつくつた小円板形 の器（直徑 $30.5 \mathrm{~mm}$, 厚さ $16.5 \mathrm{~mm}$ ）で, その一部は牛円形の蓋（A）にな つている。他の部分 (B) K，小さい円筒形の反応室が三つ開けてある(a， b, c)。レ゙ずれる同形, 同大で,直徑は $6.5 \mathrm{~mm}$, 深さ $14 \mathrm{~mm}$, 容積は $0.46 \mathrm{cc}$ である。この反応室の一つ（C）は，この器の中央部に位し, 他の二つ（a） （b）は，(c) の両側に正し〈対称的に位置している。第1四に明膫に示して あるが,この三つの反応室は,んすかれるその内筒軸を本行とし，この軸はいず れも(A)と(B) との境の面に垂直である。この三つの反掂室 $(a, b, c)$ の各 ふに側面より小さい穴 $(\mathrm{d}, \mathrm{e}, \mathrm{f}$ )(直径約 $2 \mathrm{~mm}$ ) が開けてある。この穴もん すれる同形，同大で，支持器の側面の壁に垂直に，しかも，各反応室の中心 

アンメーター（A）圭通つて炬へ接続する。

以上說明した裝㯰の全 貌は第 4 図の写真老参照 されたい。

將来の問題

世界に出いては多くは 百記記錄式（写真式又は 肖記記铮電位差計）在用 んている。我が国の示差 熱分析実験正遠加らす の方面に向わなければな らない。

裝置の型式の多樣性に

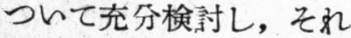
らの中で最も適当な代表 的の裝䈯式も生み出さ
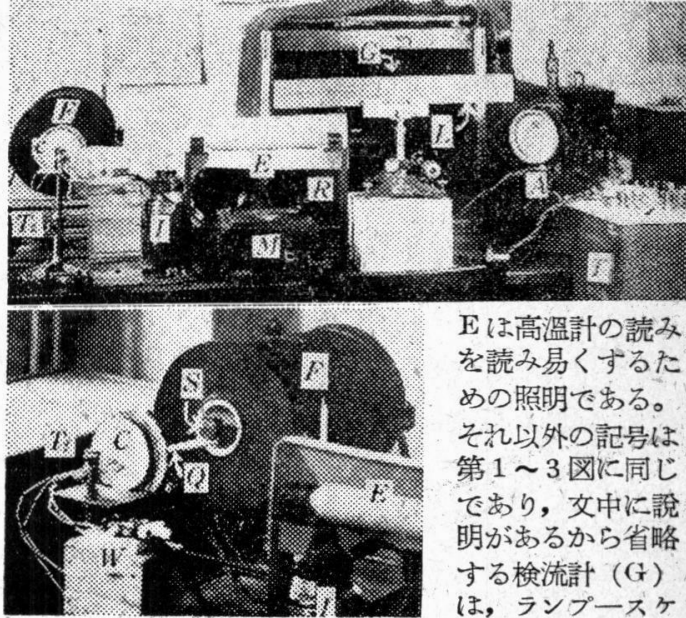

$\mathrm{E}$ は高溫計の読み を読み易くするた めの照明である。 それ以外の記号は 第 $1 \sim 3$ 図に同じ であり，交中に說 明があるから省略 する検流計 (G) は, ランプースケ ール (L) の後住見える箱の奧に設置されている。抵 抗箱 (R) は，この写真には見えないが，同じくラン プースヶール (L) の後の箱の中に說明されている。 第
図

なければならないがこの方面の研究は未だ世界の学界において軌道に乗つ ていない。国際粘土研究委員会は，その最初の仕事に示差熱分析裝㽡及びそ の実験方法の検封を揭げていたが，現在までその活動狀況は進展していない ように見える。最近 Arkansas 大学の W. J. Smother は，倜人的にこの問 題を取り上げ，各国の実験狀況を集めつつある。

な和筆者の実験室においては常溫より $150^{\circ} \mathrm{C}$ まの間の熱反応の狀態を 記錄する簡易な裝置を完成し，実験が開始されんとしている。この結果は將 来の問題であるが，常溫より $150^{\circ} \mathrm{C}$゙の゙間に著しい脫水をみるモンモり ロナイト, 加承ハロイサイトその他の粘土鉱物の研究についてこの裝置が有 効であることを期待している。

終りに本篇に紹介した示差熱分析裝置及び最近に完成した常溫より $150^{\circ} \mathrm{C}$

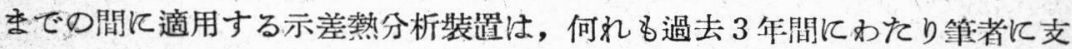
給された利学研究費を使用して完成し得たるのである。ここに特記して謝意 老表わす。 


\section{交}

(1) H. Le Chatelier : Bull. Soc. Franee. Miner., 10, 284 (1887)

(2) 例えば J. L. Kulp, P. Kent, and P. F. Kerr : Amer. Miner., 36, 643. (1951)

（3）例えば R. L. Manly : Amer. Miner., 35, 108 (1950)

(4) M. Wittels : Amer. Miner., 37, 28 (1952)

(5) H. H. Heady : Amer. Miner., 37, 804 (1952)

(6) R. E. Grim and R. A. Rowland : Jour. Amer. Ceramic Soc., 27, 5 (19 44) Amer. Miner., 23, 746, 801 (1942)

(7) P. E. Kerr and J. L. Kulp : Amer. Miner., 33, 387 (1948)

(8) L. H. Berkelhamer : U. S. Bur. Mines, Rept. Invest., 3762 (1944)

(9) S. Kozu and M. Masuda : Sci. Rept. Tohoku Inp. Univ., Third Ser., Vol. III, 33 (1926 1929)

(10) 河島千尋 : 案業原料, 第 2 集 (学術図畫出版社), 62 (1949)

（11） 大坪義雄，加藤忠雄：日本化学雜誌，71，475 (1950)

(12) T. Sudo, K. Nagasawa, M. Amafugi, M. Kimura, S. Honda, T. Muto, and M. Tanemura : Jour. (Geol. Soc. Jap., 58, 115, (1952)

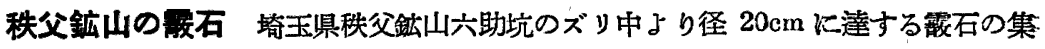
合体を採集した。このるのは無色透明乃至斗唀明の柱狀結晶で放射狀に集合し個体の 長さは数cmに達する。柱の末端部ては結晶が遊離し銳い錐面と, 銳鈍二種の短軸庆面 を認め得るが，ズリ中にあつたため殆んぞ大部分が破損せられ面指数は決定し蜼い。 定性分析では $\mathrm{Ca}$ と $\mathrm{CO}_{2}$ のみで, $\mathrm{Sr}, \mathrm{Ba}$ の存在は認められなかつたが，一部に灰黑色 を呈し㱠んど不透明汇近い個所があり，この部分では著量の $\mathrm{Pb}$ を検出し得た。然し これと同時に $\mathrm{H}_{2} \mathrm{~S}$ を放つことよりしてこのるのが霞石と白鉛鉱の類質同像混合体て ある tarnowitzite でなく, 単に霞石中に方鉛鉣を包有しているに過ぎないことが明 らかである。向この灰黑色の部は白色の部涹化している。

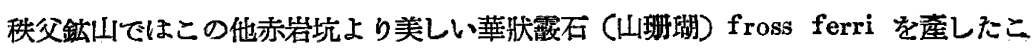
そがある。(桜井欽一，藤山家德） 